\title{
Selective digestive or oropharyngeal decontamination and topical oropharyngeal chlorhexidine for prevention of death in general intensive care: systematic review and network meta-analysis
}

\begin{abstract}
Objectives To determine the effect on mortality of selective digestive decontamination, selective oropharyngeal decontamination, and topical oropharyngeal chlorhexidine in adult patients in general intensive care units and to compare these interventions with each other in a network meta-analysis.

Design Systematic review, conventional meta-analysis, and network meta-analysis. Medline, Embase, and CENTRAL were searched to December 2012. Previous meta-analyses, conference abstracts, and key journals were also searched. We used pairwise meta-analyses to estimate direct evidence from intervention-control trials and a network meta-analysis within a Bayesian framework to combine direct and indirect evidence.

Inclusion criteria Prospective randomised controlled trials that recruited adult patients in general intensive care units and studied selective digestive decontamination, selective oropharyngeal decontamination, or oropharyngeal chlorhexidine compared with standard care or placebo.

Results Selective digestive decontamination had a favourable effect on mortality, with a direct evidence odds ratio of 0.73 ( $95 \%$ confidence interval 0.64 to 0.84 ). The direct evidence odds ratio for selective oropharyngeal decontamination was 0.85 (0.74 to 0.97 ). Chlorhexidine was associated with increased mortality (odds ratio $1.25,1.05$ to 1.50 ). When each intervention was compared with the other, both selective digestive decontamination and selective oropharyngeal decontamination were superior to chlorhexidine. The difference between selective digestive decontamination and selective oropharyngeal decontamination was uncertain.
\end{abstract}

Conclusion Selective digestive decontamination has a favourable effect on mortality in adult patients in general intensive care units. In these patients, the effect of selective oropharyngeal decontamination is less certain. Both selective digestive decontamination and selective oropharyngeal decontamination are superior to chlorhexidine, and there is a possibility that chlorhexidine is associated with increased mortality.

\section{Introduction}

The bacterial ecology of the oropharynx of patients in intensive care units undergoes substantial alteration. ${ }^{12}$ This can lead to ventilator associated pneumonia, other infections, and death. In an attempt to reduce the incidence of these complications, approaches to decontamination include various forms of antibiotic prophylaxis or the use of topical oropharyngeal antiseptic agents (mostly chlorhexidine). Antibiotic prophylaxis can include any combination of oropharyngeal, intragastric, and intravenous antibiotics. There are, however, two main approaches: selective digestive decontamination (SDD) and selective oropharyngeal decontamination (SOD).

Selective digestive decontamination consists of oropharyngeal and gastric application of non-absorbable antibiotics-often polymyxin, tobramycin, and amphotericin—along with a short course of an intravenous antibiotic, often cefotaxime.

Oropharyngeal antibiotics are applied as a paste, usually four times a day, during routine mouth care; gastric antibiotics are administered as a suspension through a nasogastric tube. Surveillance bacteriology, often twice a week, can be used to assess efficacy of decontamination. The choice of therapeutic antibiotics aims to minimise interference with the native anaerobic flora by avoiding agents such as broad spectrum penicillins. Selective oropharyngeal decontamination is the application of the topical antibiotic paste to the oropharynx only, 
without enteral or empirical intravenous antibiotics. ${ }^{3}$ Chlorhexidine is applied as part of routine mouth care in gel or liquid form up to four times a day.

There has been considerable debate about the role of antibiotic prophylaxis, ${ }^{4-6}$ and antibiotic prophylaxis is seldom used in the United Kingdom. ${ }^{7}$ Topical oropharyngeal antiseptic agents (usually chlorhexidine) have, by contrast, gained more widespread acceptance and appear as a key recommendation in $\mathrm{UK},{ }^{8}$ European, ${ }^{9}$ and $\mathrm{US}^{10}$ guidelines. Nevertheless, interest in this topic remains current. ${ }^{11}$

Numerous meta-analyses of antibiotic and antiseptic prophylaxis have been published over the years. A 2009 Cochrane review suggested that mortality was significantly reduced by selective digestive decontamination. ${ }^{12}$ Another review and meta-analysis from 2007 concluded that mortality was unaffected by oropharyngeal antibiotic or antiseptic decontamination. ${ }^{13}$ More recent meta-analyses of oropharyngeal antiseptics (mostly chlorhexidine) have focused on the incidence of ventilator associated pneumonia, ${ }^{14-16}$ although some meta-analyses of oropharyngeal chlorhexidine have reported a trend towards increased mortality. ${ }^{15} 17$

Despite the favourable results seen in meta-analyses of selective digestive decontamination, interpretation should be tempered by the use of standard care as a control group in the contributory trials. Given the likely widespread use of chlorhexidine, any putative mortality advantage of selective digestive decontamination or selective oropharyngeal decontamination needs to be re-defined. As we are not aware of any clinical trials directly comparing selective digestive decontamination or selective oropharyngeal decontamination with topical chlorhexidine, we aimed to use a network meta-analysis to compare the effect of these interventions on mortality. This required us to undertake an updated systematic review looking for randomised controlled trials reporting the effect of selective digestive decontamination, selective oropharyngeal decontamination, and topical chlorhexidine on mortality in adult patients in general intensive care units. We also wanted to update conventional intervention-control meta-analyses of the three interventions in light of any recent studies. We elected not to study the outcome of ventilator associated pneumonia as we consider mortality to be the most robust outcome, and this was the focus of recent large trials of selective digestive decontamination. ${ }^{18} 19$

\section{Method}

\section{Sources of data}

We searched Medline, Embase, and the Cochrane Register of Clinical Trials from 1984 until December 2012. We constructed a search strategy around patients in intensive care, intervention with antibiotic or antiseptic prophylaxis, and the outcome of death. The Medline search strategy is shown in the appendix and similar strategies were applied to the Embase and CENTRAL databases. There were no language restrictions. We screened results of the database searches by title and abstract. Given the extent of previous systematic reviews, we reviewed recent meta-analyses (published from 2005 to $2012^{12-16 ~ 20-28}$ ) for included studies that were missed in database searches. Congress abstracts were searched from 2005 to 2012 for the European Society for Intensive Care Medicine, Society for Critical Care Medicine, Symposium of Intensive Care and Emergency Medicine, and Chest. The contents pages of the journals Intensive Care Medicine, Critical Care Medicine, Chest, Critical Care, American Journal of Respiratory and Critical Care Medicine, Journal of Hospital Infection, and Infection Control and Hospital Epidemiology were reviewed from January 2005 to December 2012. The website controlled-trials.com was used to search registers of clinical trials. We did not search for unpublished studies or contact experts in the field. We wrote to authors if indicated.

\section{Inclusion criteria}

We sought prospective randomised controlled clinical trials in adult patients in general intensive care units. We did not stipulate placebo control or blinding. We defined "selective digestive decontamination" as the application of a combination of poorly absorbable antibiotics to the oropharynx and the stomach combined with empirical intravenous antibiotics. "Selective oropharyngeal decontamination" was defined as the application of a combination of poorly absorbable antibiotics only to the oropharynx. "Chlorhexidine" was defined as the application of any concentration of chlorhexidine in any formulation to the oropharynx. The control group must have received only standard care or placebo.

\section{Exclusion criteria}

We excluded trials that recruited only children, populations not in intensive care, and specialised populations (such as cardiac surgery and liver transplantation). We excluded trials in which both groups received active topical drugs or in which the control group received empirical intravenous antibiotics. Finally we excluded studies combining oropharyngeal and gastric application of antibiotics or gastric or subglottic application alone from the selective oropharyngeal decontamination meta-analysis.

\section{Quality assessment}

We summarised potential biases with the Cochrane risk of bias tool. There are six domains: sequence generation; allocation concealment; blinding; if the outcomes reported were prespecified; completeness of outcome data; and other potential sources of bias. We have also presented information on each study to show potential issues of clinical heterogeneity.

\section{Data extraction}

Results were extracted from the included studies, from our own communication with authors, or from previous meta-analyses if intention to treat data had been verified with the original study authors.

\section{Consensus}

Two authors (RP, JG) independently performed study inclusion, data extraction, and quality assessment. Disagreement at the stage of abstract screening was resolved by inclusion of the full paper for review. Disagreement at later stages was resolved by discussion. Our approaches to studies with a three arm design are presented in the appendix.

\section{Statistical methods Intervention-control pairwise meta-analyses}

We summarised data from each study with log odds ratios and $95 \%$ confidence intervals. This approach was used to allow the inclusion of the study by de Smet and colleagues, ${ }^{19}$ which used a cluster randomised crossover design analysed by the authors using multilevel logistic regression. We used the log odds ratios and standard errors that de Smet and colleagues ${ }^{19}$ reported and calculated the log odds ratios and standard errors for the remaining studies based on the reported events and sample sizes. 
Forest plots are included as a visual aid to interpret the direct evidence. Pairwise meta-analyses were done in Review Manager (RevMan), version 5.0 (Cochrane Collaboration, 2008).

\section{Network meta-analysis}

We used a generalised linear modelling framework as outlined in Dias and colleagues ${ }^{29}$ to do a network meta-analysis. A "trial level" approach was used, in which the data modelled were the summary log odds ratios and standard errors for each trial as outlined above. All model parameters were estimated within a Bayesian framework with WinBUGS software. ${ }^{30}$ We present estimates of treatment effects as odds ratios and $95 \%$ central credible intervals $(\mathrm{CrI})$. The credible interval shows the degree of uncertainty around estimated treatment effects.

We also calculated individual estimates of the probability of death for each intervention. These estimates were derived from the model by using a baseline distribution for the probability of death in the control group, in combination with the odds ratio between each intervention and control. Vague prior distributions were used on the necessary parameters: the log odds ratios of intervention procedures versus control and the standard deviation between studies. A run-in period of 50000 iterations was adequate to achieve convergence, and a further 100000 samples were taken.

\section{Results}

\section{Systematic review}

We identified 29 studies as suitable for inclusion ${ }^{18} 19$ 31-57 (figure

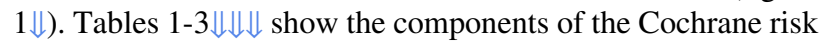

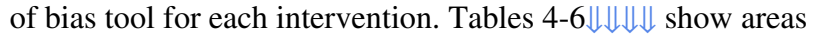
of potential clinical heterogeneity between the studies and our data source. Raw outcome data are presented in table A in the appendix.

\section{Intervention-control pairwise meta-analyses}

The random effects estimate for selective digestive decontamination compared with control on mortality gave an odds ratio of 0.73 (95\% confidence interval 0.64 to 0.84 ), favouring selective digestive decontamination (fig $2 \Downarrow$ ). For selective oropharyngeal decontamination and chlorhexidine the odds ratios were 0.85 (0.74 to 0.97 ) and 1.25 (1.05 to 1.50), respectively (figs $3 \Downarrow$ and $4 \Downarrow$ ). The only direct evidence for selective digestive decontamination compared with selective oropharyngeal decontamination was from a single trial, ${ }^{19}$ which gave an odds ratio of 0.97 (0.79 to 1.18). Results are summarised in table $7 \Downarrow$.

\section{Results of network meta-analyses}

The odds ratios (95\% credible interval) for mortality for active treatment compared with control were 0.74 (0.63 to 0.86$)$ for selective digestive decontamination, 0.82 (0.62 to 1.02$)$ for selective oropharyngeal decontamination, and 1.23 (0.99 to 1.49) for chlorhexidine (table $7 \Downarrow$ ). For the comparison between treatments, the odds ratios were 0.61 ( 0.47 to 0.78 ) for selective digestive decontamination compared with chlorhexidine and 0.67 (0.48 to 0.91 ) for selective oropharyngeal decontamination compared with chlorhexidine. There was uncertainty around the difference between selective digestive decontamination and selective oropharyngeal decontamination. Table 8 shows probabilistic ranking of interventions $\Downarrow$.

\section{Discussion}

Using a network meta-analysis to compare each intervention indirectly, we conclude that both selective digestive decontamination and selective oropharyngeal decontamination are superior to chlorhexidine in preventing death in adults in intensive care. This suggests that the mortality advantage of both these options remains relevant even if chlorhexidine is widely used. Any difference between these treatments is inconclusive, with considerable uncertainty.

Our finding that selective digestive decontamination is associated with a survival benefit in adults in general intensive care units agrees with the conclusions of earlier meta-analyses, but we have now integrated the results of a large cluster randomised crossover trial. Results were similar with both conventional and Bayesian analysis. Selective oropharyngeal decontamination was associated with a reduction in death in the meta-analysis of direct evidence. Contrary to our expectations, use of oropharyngeal chlorhexidine was associated with an increase in mortality in adults in general intensive care units.

\section{Limitations of our study}

Despite our inclusion criteria, our results are limited by the inevitable heterogeneity among the included studies (tables

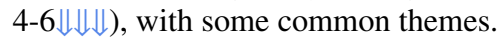

Within the chlorhexidine studies, the concentration of chlorhexidine used varied from $0.12 \%$ to $2 \%$ and the number of daily applications varied from one to four. In addition, the duration of the course of treatment varied and in one study was limited to seven days. ${ }^{54}$

Within the selective digestive decontamination studies, most were not blinded and were not placebo controlled. Of those that were blinded, ${ }^{36}{ }^{38}{ }^{39}$ only one explicitly reported concealment of microbial culture results. ${ }^{39}$ We consider that this lack of blinding would have had the least influence on the robust outcome of mortality. We could not find any suggestion of differential treatment of patients in the active treatment group over control patients, although we cannot entirely exclude it. Infected patients were excluded in three studies. ${ }^{34}{ }^{37} 38$ There was some variability in the exact antimicrobial regimen used; the influence of different regimens has previously been discussed ${ }^{58}$ and has been shown to influence at least infective outcomes. ${ }^{42}$ Two studies differed slightly in their protocols by locally decontaminating blind bowel loops and tracheal stomas and by treating persistent tracheal colonisation with aerosolised polymyxin or amphotericin. ${ }^{18} 19$

For each included selective digestive decontamination study, the total proportion of patients in the intensive care unit that were included in the trial was generally unclear. The only included study to use a whole unit approach ${ }^{18}$ showed a mortality benefit that was greater than that seen in meta-analyses (although problems with this study have been highlighted. $)^{59} 60$ Thus the generalisability of these studies to a unit where selective digestive decontamination or selective oropharyngeal decontamination is applied to every patient needs to be considered as selective digestive decontamination can alter the ecology of the unit. ${ }^{32} 6162$

When we considered all studies, there was variability in the minimum predicted ventilator time or stay in the intensive care unit. The proportion of ventilated patients varied from $36 \%$ in one study ${ }^{55}$ to $100 \%$.

A network meta-analysis rests on the comparability of a common control group. Given the temporal variation (year of publication ranging from 1989 to 2011) and wide geographic representation 


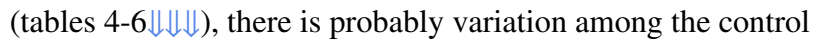
groups of the included studies. Control group treatments were generally poorly detailed, although we have identified some variation-for example, the use of topical bicarbonate ${ }^{48}$ or potassium permanganate. ${ }^{55}$ When other control group treatments were described, they were generally limited to the use of gastric ulcer protection or non-pharmacological mouth care strategies. When we considered the effect of chlorhexidine on mortality, mortality was not the primary outcome of any of the included studies and a significant increase in mortality was seen in only one $^{54}$ of the 11 studies. Additionally, we are aware of one further study ${ }^{63}$ of the use of oropharyngeal chlorhexidine that could have fulfilled our inclusion criteria, but we were unable to include it as we could not obtain mortality data.

\section{Implications of this study}

In adult patients in general intensive care units, and within the limits of a network meta-analysis, we propose that both selective digestive decontamination and selective oropharyngeal decontamination are superior to chlorhexidine. In keeping with results of earlier studies, we have shown that selective digestive decontamination is associated with reduced mortality. We raise the possibility that oropharyngeal chlorhexidine might be associated with an increase in mortality, and we therefore question whether oropharyngeal chlorhexidine is "safe and effective." ${ }^{11}$ Certainly our findings are at odds with the apparently favourable effects of chlorhexidine on the incidence of ventilator associated pneumonia, ${ }^{14-16}$ although the attributable mortality of this might be small. ${ }^{64} \mathrm{We}$ consider that the role of oropharyngeal chlorhexidine in these patients needs to be explored further. We agree that it would be appropriate to undertake additional prospective studies comparing selective digestive decontamination, selective oropharyngeal decontamination, and chlorhexidine ${ }^{1165}$ after barriers to implementation or any further trials have been explored. ${ }^{66}$

We thank Amanda Wright for librarian services, Silvia Hernandez for translation services and obtaining additional information from a study author, and Artur Pryn. We also thank Angela Berry, Cindy Munro, and Frank Scannapieco for providing additional data; and Fernando Bellissimo Rodrigues, Michele Darby, Mirelle Koeman, Mercedes Palomar, and Miguel Sanchez Garcia for providing additional information. Contributors: RP and GM designed the study. RP and JG did the literature search, reviewed studies for inclusion, assessed the included studies, and extracted data. GM analysed the data. All three authors wrote, reviewed, and then approved the manuscript. RP is guarantor. Funding: This research received no specific grant from any funding agency in the public, commercial, or not-for-profit sectors.

Competing interests: All authors have completed the ICMJE uniform disclosure form at www.icmje.org/coi_disclosure.pdf and declare: no support from any organisation for the submitted work; no financial relationships with any organisations that might have an interest in the submitted work in the previous three years; no other relationships or activities that could appear to have influenced the submitted work.

Ethical approval: Not required.

Data sharing: No additional data available.

Transparency: The lead author (the manuscript's guarantor) affirms that the manuscript is an honest, accurate, and transparent account of the study being reported; that no important aspects of the study have been omitted; and that any discrepancies from the study as planned (and, if relevant, registered) have been explained.

Johanson WG, Pierce AK, Sanford JP, Thomas GD. Nosocomial respiratory infections with Gram-negative bacilli: the significance of colonization of the respiratory tract. Ann Int Med 1972;77:701-6.
2 Garrouste-Orgeas M, Chevret S, Arlet G, Marie O, Rouveau M, Popoff N, et al. Oropharyngeal or gastric colonization and nosocomial pneumonia in adult intensive care unit patients a prospective study based on genomic DNA analysis. Am J Respir Crit Care Med 1997;156:1647-55

3 De Smet A-M, Bonten MJ, Kluytmans JA. For whom should we use selective decontamination of the digestive tract? Curr Opin Infect Dis 2012;25:211-7.

Bonten MJ Brun-Buisson C, Weinstein RA. Selective decontamination of the digestive tract: to stimulate or stifle. Intensive Care Med 2003:29:672-6.

5 Van Saene HK, Petros AJ, Ramsay G, Baxby D. All great truths are iconoclastic: selective decontamination of the digestive tract moves from heresy to level 1 truth. Intensive Care Med 2003;29:677-90.

6 Kollef MH. Selective digestive decontamination should not be routinely employed. Chest 2003;123:464-8S.

7 Bastin AJ, Ryanna KB. Use of selective decontamination of the digestive tract in United Kingdom intensive care units. Anaesthesia 2009;64:46-9.

8 National Institute for Health and Clinical Excellence. Technical patient safety solutions for ventilator-associated pneumonia in adults. www.nice.org.uk/nicemedia/pdf/ PSG002Guidance.pdf

9 Rello J, Lode H, Cornaglia G, Masterton R. A European care bundle for the prevention of ventilator associated pneumonia. Intensive Care Med 2010;36:773-80.

10 How-to Guide: prevent ventilator-associated pneumonia. Institute for Healthcare Improvement, 2012. www.ihi.org.

11 Walden AP, Bonten MJ, Wise MP. Should selective digestive decontamination be used in critically ill patients? BMJ 2012;345:e6697.

12 Liberati A, D'Amico R, Pifferi S, Torri V, Brazzi L, Parmelli E. Antibiotic prophylaxis to reduce respiratory tract infections and mortality in adults receiving intensive care. Cochrane Database Syst Rev 2009:4:CD000022.

13 Chan EY, Ruest A, Meade MO, Cook DJ. Oral decontamination for prevention of pneumonia in mechanically ventilated adults: systematic review and meta-analysis. $B M J$ 2007;334:889-93.

14 Labeau SO, Van de Vyver K, Brusselaers N, Vogelaers D, Blot SI. Prevention of ventilator-associated pneumonia with oral antiseptics: a systematic review and meta-analysis. Lancet Infect Dis 2011;11:845-54.

15 Pileggi C, Bianco A, Flotta D, Nobile CGA, Pavia M. Prevention of ventilator-associated pneumonia, mortality and all intensive care unit acquired infections by topically applied antimicrobial or antiseptic agents: a meta-analysis of randomized controlled trials in intensive care units. Crit Care 2011;15:R115.

16 Carvajal C, Pobo A, Diaz E, Lisboa T, Llaurado M, Rello J. Higiene oral con clorhexidina para la prevencion de neumonia en pacientes intubatos: revision sistematica de ensayos clinicos aleatorizados. Med Clin (Barc) 2010;135:491-7.

17 Pugh RJ, Rathbone P. Oral chlorhexidine to prevent nosocomial pneumonia in critically ill patients: a systematic review and meta-analysis. Crit Care 2010;14(suppl 1):85.

18 De Jonge E, Schultz MJ, Spanjaard L, Bossuyt PM, Vroom MB, Dankert J, et al. Effects of selective decontamination of digestive tract on mortality and acquisition of resistant bacteria in intensive care: a randomised controlled trial. Lancet 2003;362:1011-6.

19 De Smet AM, Klutymans JA, Cooper BS, Mascini EM, Benus RF, van der Werf TS, et al. Decontamination of the digestive tract and oropharynx in ICU patients. N Engl J Med 2009;360:20-31.

20 Chlebicki MP, Safdar N. Topical chlorhexidine for prevention of ventilator-associated pneumonia: a meta-analysis. Crit Care Med 2007;35:595-602.

21 Kola A, Gastmeier P. Efficacy of oral chlorhexidine in preventing lower respiratory tract infections. Meta-analysis of randomized controlled trials. J Hosp Inf 2007;66:207-16.

22 Pineda LA, Saliba RG, El Solh AA. Effect of oral decontamination with chlorhexidine on the incidence of nosocomial pneumonia: a meta-analysis. Crit Care 2006;10:R35.

23 Schultz MJ, Haas LE. Antibiotics or probiotics as preventive measures agains ventilator-associated pneumonia: a literature review. Crit Care 2011;15:R18.

24 Silvestri L, van Saene HKF, Zandstra DF, Marshall JC, Gregori D, Gullo A. Impact of selective decontamination of the digestive tract on multiple organ dysfunction syndrome: systematic review of randomized controlled trials. Crit Care Med 2010;38:1370-6.

25 Silvestri L, van Saene H K F, Weir I, Gullo A. Survival benefit of the full selective digestive decontamination regimen. J Crit Care 2009;24:474.e7-14.

26 Silvestri L, van Saene H K F, Casarin A, Berlot G, Gullo A. Impact of selective decontamination of the digestive tract on carriage and infection due to Gram-negative and Gram-positive bacteria: a systematic review of randomised controlled trials. Anaesth Intensive Care 2008;36:324-38.

27 Silvestri L, van Saene HK, Milanese M, Gregori D, Gullo A. Selective decontamination of the digestive tract reduces bacterial bloodstream infection and mortality in critically ill patients. Systematic review of randomised controlled trials. J Hosp Infect 2007;65:187-203.

28 Van Till JWO, van Ruler O, Lamme B, Weber RJ, Reitsma JB, Boermeester MA Single-drug therapy or selective decontamination of the digestive tract as antifungal prophylaxis in critically ill patients: a systematic review. Crit Care 2007;11:R126.

29 Dias S, Welton NJ, Sutton AJ, Ades AE. A generalised linear modelling framework for pairwise and network meta-analysis of randomised controlled trials. NICE DSU Technical Support Document 2. 2012. www.nicedsu.org.uk

30 Lunn DJ, Thomas A, Best N, Spiegelhalter D. WinBUGS-a Bayesian modelling framework: concepts, structure, and extensibility. Statistics Computing 2000;10:325-37.

31 Aerdts SJ, van Dalen R, Clasener HA, Festen J, van Lier HJ, Vollard EJ. Antibiotic prophylaxis of respiratory tract infection in mechanically ventilated patients: a prospective, blinded, randomised trial of a novel regimen. Chest 1991;100:783-91.

32 Blair P, Rowlands BJ, Lowry K, Webb H, Armstrong P, Smilie J. Selective decontamination of the digestive tract: a stratified, randomised, prospective study in a mixed intensive care unit. Surgery 1991;110:303-10.

33 Boland JP, Sadler DL, Stewart WA, Wood DJ, Zerick W, Snodgrass KR. Reduction of nosocomial respiratory tract infection in the multiple trauma patient requiring mechanical ventilation by selective parenteral and enteral antisepsis regimen (SPEAR) in the intensive care unit. XVII Congress of Chemotherapy, 1991.

34 Cockerill FR, Muller SR, Anhalt JP, Marsh HM, Farnell MB, Mucha P, et al. Prevention of infection in critically ill patients by selective decontamination of the digestive tract. Ann Intern Med 1992;117:545-53.

35 Jacobs S, Foweraker JE, Roberts SE. Effectiveness of selective decontamination of the digestive tract in an ICU with a policy encouraging a low gastric $\mathrm{pH}$. Clin Intensive Care 1992;3:52-8.

36 Krueger WA, Lenhart F-P, Neeser G, Ruckdeschel G, Schreckhase H, Eissnet H-J, et al. Influence of combined intravenous and topical antibiotic prophylaxis on the incidence of infections, organ dysfunctions and mortality in critically ill surgical patients: a prospective, 


\section{What is already known on this topic}

Numerous studies and meta-analyses have shown a mortality benefit with use of selective digestive decontamination in patients in intensive care

Meta-analyses have shown that oropharyngeal chlorhexidine is associated with a reduced incidence of ventilator associated pneumonia, without a measurable effect on mortality

\section{What this paper adds}

This network meta-analysis showed that both selective digestive decontamination and selective oropharyngeal decontamination confer a mortality benefit when compared with chlorhexidine in adult patients in general intensive care units

In these patients, selective digestive decontamination was associated with reduced mortality, as in earlier meta-analyses, but the current analysis integrated a large recent cluster crossover study

It is possible that use of chlorhexidine is associated with an increase in mortality

stratified, randomised, double blind placebo controlled clinical trial. Am J Respir Crit Care Med 2002;166:1029-37

37 Palomar M, Alvarez-Lerma F, Jorda R, Bermejo B. Prevention of nosocomial infection in mechanically ventilated patients: selective digestive decontamination versus sucralfate. Clin Intensive Care 1997:8:228-35.

38 Rocha LA, Martin MJ, Pita S, Paz J, Seco C, Margusino L, et al. Prevention of nosocomial infection in critically ill patients by selective decontamination of the digestive tract: a randomised, double-blind, placebo controlled study. Intensive Care Med 1992;18:398-404

39 Sanchez Garcia M, Cambronero Galache JA, Lopez Diaz J, Cerda Cerda E, Rubio Blasco $\mathrm{J}$, Gomez Aguinaga MA, et al. Effectiveness and cost of selective decontamination of the digestive tract in critically ill intubated patients: a randomised, double-blind, placebo controlled multicentre trial. Am J Respir Crit Care Med 1998;158:908-16.

40 Stoutenbeek CP, van Saene HK, Little RA, Whitehead A. The effect of selective decontamination of the digestive tract on mortality in multiple trauma patients: a multi-cente randomised controlled trial. Intensive Care Med 2007;33:261-70.

41 Ulrich C, Harinck-de Weerd JE, Bakker NC, Jacz K, Doornbos L, de Ridder VA. Selective decontamination of the digestive tract with norfloxacin in the prevention of ICU acquired infections: a prospective randomised study. Intensive Care Med 1989;15:424-31.

42 Verwaest C, Verhaegen J, Ferdinande P, Schetz M, van den Berghe G, Verbist L, et al. Randomised, controlled trial of selective digestive decontamination in 600 mechanically ventilated patients in a multidisciplinary intensive care unit. Crit Care Med 1997;25:63-71.

43 Winter R, Humphreys H, Pick A, MacGowan AP, Willatts SM, Speller DC. A controlled trial of selective decontamination of the digestive tract in intensive care and its effect on nosocomial infection. J Antimicrob Chemother 1992;30:73-87.

44 Bergmans DC, Bonten MJ, Gaillard CA, Paling JC, van der Geest S, van Tiel FH, et al. Prevention of ventilator-associated pneumonia by oral decontamination: a prospective, randomised, double-blind, placebo-controlled study. Am J Respir Crit Care Med 2001;164:382-8.

45 Pugin J, Auckenthaler R, Lew DP, Suter PM. Oropharyngeal decontamination decreases incidence of ventilator-associated pneumonia. JAMA 1991:265:2704-10.

46 Rios F, Maskin B, Saenz Valiente A, Galante A, Cazes Camarero P, Aguilar L, et al. Prevention of ventilator associated pneumonia (VAP) by oral decontamination (OD) Prospective, randomised, double-blind, placebo-controlled study. Proceedings of the American Thoracic Society 2005:A820.

47 Bellissimo-Rodrigues F, Bellissimo-Rodrigues WT, Viana JM, Teixeria GC, Nicolini E, Auxiliadora-Martins $\mathrm{M}$, et al. Effectiveness of oral rinse with chlorhexidine in preventing nosocomial respiratory tract infections among intensive care unit patients. Infect Control Hosp Epidemiol 2009;30:952-8.

48 Berry AM, Davidson PM, Masters J, Rolls K, Ollerton R. Effects of three approaches to standardized oral hygiene to reduce bacterial colonization and ventilator associated pneumonia in mechanically ventilated patients: a randomised control trial. Int $J$ Nursing Stud 2011;48:681-8.

49 Cabov T, Marcan D, Husedznovic I, Skrlin-Subic J, Bosnjak D, Sestan-Crnek S, et al. The impact of oral health and $0.2 \%$ chlorhexidine oral gel on the prevalence of nosocomial infections in surgical intensive care patients: a randomized placebo controlled study. Wien Klin Wochenschr 2010;122:397-404.

50 Fourrier F, Cau-Pottier E, Boutigny H, Roussel-Delvallez M, Jourdain M, Chopin C. Effects of dental plaque antiseptic decontamination of bacterial colonization and nosocomial infections in critically ill patients. Intensive Care Med 2000;26:1239-47.

51 Fourrier F, Dubois D, Pronnier P, Herbecq P, Leroy O, Desmettre T, et al. Effect of gingival and dental plaque antiseptic decontamination on nosocomial infections acquired in the intensive care unit: a double-blind placebo-controlled multicenter study. Crit Care Med 2005;33:1728-35.
52 Koeman M, van der Ven AJ, Hak E, Joore HC, Kaasjager K, de Smet AM, et al. Oral decontamination with chlorhexidine reduces the incidence of ventilator-associated pneumonia. Am J Respir Crit Care Med 2006;173:1348-55.

53 MacNaughton PD, Bailey J, Donlin N, Branfield P, Williams A, Rowswell H. A randomised controlled trial assessing the efficacy of oral chlorhexidine in ventilated patients. Intensive Care Med 2004;30:S12

54 Munro CL, Grap MJ, Jones DJ, McClish DK, Sessler CN. Chlorhexidine, toothbrushing and preventing ventilator associated pneumonia in critically ill adults. Am J Crit Care 2009;18:428-38.

55 Panchabhai TS, Dangayach NS, Krishnan A, Kothari VM, Karnad DR. Oropharyngeal cleansing with $0.2 \%$ chlorhexidine for prevention of nosocomial pneumonia in critically ill patients. Chest 2009;135:1150-6.

56 Scannapieco FA, Yu J, Raghavendran K, Vacanti A, Owens SI, Wood K, Mylotte JM. A randomized trial of chlorhexidine gluconate on oral bacterial pathogens in mechanically ventilated patients. Crit Care 2009;13:R117.

57 Tantipong H, Morkchareonpong C, Jaiyindee S, Thamlikitkul V. Randomised controlled trial and meta-analysis of oral decontamination with $2 \%$ chlorhexidine solution for the prevention of ventilator-associated pneumonia. Infect Control Hospital Epidemiol 2008;29:131-6.

58 Van Saene HK, Stoutenbeek CP, Stoller JK. Selective decontamination of the digestive tract in the intensive care unit: current status and future prospects. Crit Care Med 1992;20:691-703.

59 Verbrugh HA. Selective decontamination of digestive tract in intensive care. Lance 2003;362:2117-8.

60 De Jonge E, Schultz M, Spanjaard L, Bossuyt P, Kesecioglu J. Selective decontamination of digestive tract in intensive care. Lancet 2003;362:2119-20.

61 Bonten MJ, Gaillard CA, Johanson WG, van Tiel FH, Smeets HG, van der Geest S, et al. Colonisation in patients receiving and not receiving topical antimicrobial prophylaxis. $A m$ J Respir Crit Care Med 1994;150:1332-40.

62 Humphreys $\mathrm{H}$, Winter $\mathrm{R}$, Pick $\mathrm{A}$. The effect of selective decontamination of the digestive tract on gastrointestinal enterococcal colonisation in ITU patients. Intensive Care Med 1992;18:459-63

63 Tad-Y D, Soueidan A, Tehrani H, Visconti E, Bakoss I, El-Kass G, et al. Efficacy of chlorhexidine oral decontamination in the prevention of ventilator-associated pneumonia. Chest 2007;132:498a.

64 Bekaert M, Timsit J-F, Vansteelandt S, Depuydt P, Vesin A, Garrouste-Orgeas M, et al. Attributable mortality of ventilator-associated pneumonia. A reappraisal using causal analysis. Am J Respir Crit Care Med 2011;184:1133-9.

65 Oostdijk EA, Wittekamp BH, Brun-Buisson C, Bonten MJ. Selective decontamination in European intensive care patients. Intensive Care Med 2012;38:533-8.

66 Cuthbertson BH, Francis J, Campbell MK, MacIntyre L, Seppelt I, Grinshaw J. A study of the perceived risks, benefits and barriers to the use of SDD in adult critical care units (the SuDDICU study). Trials 2010;11:117.

\section{Accepted: 03 March 2014}

\section{Cite this as: BMJ 2014;348:g2197}

This is an Open Access article distributed in accordance with the Creative Commons Attribution Non Commercial (CC BY-NC 3.0) license, which permits others to distribute, remix, adapt, build upon this work non-commercially, and license their derivative works on different terms, provided the original work is properly cited and the use is non-commercial. See: http://creativecommons.org/licenses/by-nc/3.0/. 


\section{Tables}

Table 1| Methodological aspects of included trials on effect of selective digestive decontamination (SDD) for prevention of death in adults in intensive care

\begin{tabular}{|c|c|c|c|c|c|c|}
\hline & $\begin{array}{l}\text { Adequate } \\
\text { sequence } \\
\text { generation }\end{array}$ & $\begin{array}{c}\text { Allocation } \\
\text { concealment }\end{array}$ & Blinding & Outcome prespecified & Incomplete outcome data addressed & Other bias \\
\hline Aerdts $^{31}$ & Yes & $Y_{e s}^{\star 12}$ & No & $\begin{array}{l}\text { Per protocol mortality reported } \\
\text { in published paper }\end{array}$ & $\begin{array}{l}\text { Intention to treat analysis possible from } \\
\text { previous communication with authors }{ }^{\star 12}\end{array}$ & - \\
\hline Blair $^{32}$ & Unclear & $Y_{e s}^{\star 12}$ & No & Mortality reported & $\begin{array}{l}\text { Intention to treat analysis possible from } \\
\text { data provided }\end{array}$ & - \\
\hline Boland $^{33}$ & Yes $^{* 12}$ & Unclear & Yes & Mortality not reported & $\begin{array}{l}\text { Intention to treat analysis possible from } \\
\text { previous communication with authors }{ }^{\star 12}\end{array}$ & $\begin{array}{l}\text { Published only in } \\
\text { abstract form }\end{array}$ \\
\hline Cockerill $\left.\right|^{34}$ & Yes & Yes & No & Mortality reported & Intention to treat analysis performed & - \\
\hline De Jonge ${ }^{18}$ & Yes & Yes & No & $\begin{array}{l}\text { Study powered for mortality. } \\
\text { Mortality reported }\end{array}$ & Intention to treat analysis performed & $\begin{array}{l}\text { Active and control ICUs, } \\
\text { potential for other } \\
\text { differences in care }\end{array}$ \\
\hline De Smet ${ }^{19}$ & Yes & Yes & No & $\begin{array}{l}\text { Study powered for mortality. } \\
\text { Mortality reported }\end{array}$ & $\begin{array}{l}\text { Adjusted } 28 \text { day mortality used: } \\
1979 / 1990 \text { in standard care; } 2018 / 2045 \\
\text { in SDD }\end{array}$ & $\begin{array}{l}\text { Statistical correction of } \\
\text { baseline differences } \\
\text { discussed }\end{array}$ \\
\hline $\mathrm{Jacobs}^{35}$ & Unclear & Yes & No & Mortality reported & $\begin{array}{l}\text { Intention to treat analysis possible from } \\
\text { data provided }\end{array}$ & $\begin{array}{l}\text { Uncorrected relevant } \\
\text { baseline imbalance }\end{array}$ \\
\hline Kreuger $^{36}$ & Yes & Yes & Yes & Mortality reported & Intention to treat analysis performed & - \\
\hline Palomar $^{37}$ & Yes & $Y_{e s}^{\star 12}$ & No & $\begin{array}{l}\text { Per protocol mortality reported } \\
\text { in published paper }\end{array}$ & $\begin{array}{l}\text { Intention to treat analysis possible from } \\
\text { previous communication with authors }{ }^{\star 12}\end{array}$ & $\begin{array}{l}\text { Uncorrected relevant } \\
\text { baseline imbalance }\end{array}$ \\
\hline Rocha $^{38}$ & Yes & Yes & Yes & $\begin{array}{l}\text { Per protocol mortality reported } \\
\text { in published paper }\end{array}$ & $\begin{array}{l}\text { Intention to treat analysis possible from } \\
\text { previous communication with authors }{ }^{\star 12}\end{array}$ & $\begin{array}{l}\text { Placebo group had high } \\
\text { mortality for the unit } \\
\text { norm }\end{array}$ \\
\hline Sanchez-Garcia ${ }^{39}$ & Yes & Yes & Yes & $\begin{array}{l}\text { Mortality defined secondary } \\
\text { endpoint. Mortality reported }\end{array}$ & Intention to treat analysis performed & - \\
\hline Stoutenbeek ${ }^{40}$ & Yes & Yes & No & $\begin{array}{l}\text { Mortality primary endpoint. } \\
\text { Mortality reported }\end{array}$ & $401 / 405$ analysed & $\begin{array}{l}\text { Minor baseline } \\
\text { imbalances. }\end{array}$ \\
\hline Ulrich $^{41}$ & Unclear & $\mathrm{Yes}^{\star 12}$ & No & Mortality reported (incomplete) & $\begin{array}{l}\text { Intention to treat analysis possible from } \\
\text { previous communication with authors }{ }^{\star 12}\end{array}$ & - \\
\hline Verwaest $^{42}$ & Yes & Yes & No & $\begin{array}{l}\text { Mortality a defined endpoint. } \\
\text { Mortality reported }\end{array}$ & $\begin{array}{l}\text { Intention to treat analysis possible from } \\
\text { previous communication with authors }{ }^{\star 12}\end{array}$ & - \\
\hline Winter ${ }^{43}$ & Yes & Yes & No & Mortality reported & Intention to treat analysis performed & - \\
\hline
\end{tabular}

*Information taken from Cochrane ${ }^{12}$ or Chan $^{13}$ after their correspondence with authors. 
Table 2/ Methodological aspects of included trials on effect of selective oropharyngeal decontamination (SOD) for prevention of death in adults in intensive care

\begin{tabular}{|c|c|c|c|c|c|c|}
\hline & $\begin{array}{l}\text { Adequate sequence } \\
\text { generation }\end{array}$ & $\begin{array}{l}\text { Allocation } \\
\text { concealment }\end{array}$ & Blinding & Outcome prespecified & $\begin{array}{l}\text { Incomplete outcome data } \\
\text { addressed }\end{array}$ & Other bias \\
\hline Bergmans $^{44}$ & Unclear & Yes & Yes & $\begin{array}{l}\text { Mortality defined secondary } \\
\text { endpoint. Mortality reported }\end{array}$ & $226 / 245$ patients analysed & - \\
\hline De Smet ${ }^{19}$ & Yes & Yes & No & $\begin{array}{l}\text { Study powered for mortality. } \\
\text { Mortality reported }\end{array}$ & $\begin{array}{l}\text { Adjusted } 28 \text { day mortality used: } \\
1979 / 1990 \text { in standard care; } \\
1886 / 1904 \text { in SOD }\end{array}$ & $\begin{array}{l}\text { Statistical correction of } \\
\text { baseline differences } \\
\text { discussed }\end{array}$ \\
\hline Pugin $^{45}$ & Unclear & Yes $^{\star 12}$ & Yes & $\begin{array}{l}\text { Per protocol mortality reported in } \\
\text { published paper }\end{array}$ & $\begin{array}{l}\text { Intention to treat analysis possible } \\
\text { from previous communication with } \\
\text { authors }^{\star 12}\end{array}$ & - \\
\hline $\operatorname{Rios}^{46}$ & Unclear & Unclear & Yes & $\begin{array}{l}\text { Per protocol mortality reported in } \\
\text { published paper }\end{array}$ & $96 / 116$ patients analysed & $\begin{array}{l}\text { Published only in } \\
\text { abstract form }\end{array}$ \\
\hline
\end{tabular}

*Information taken from Cochrane ${ }^{12}$ or Chan $^{13}$ after their correspondence with authors. 
Table 3| Methodological aspects of included trials on effect of topical oropharyngeal chlorhexidine for prevention of death in adults in intensive care

\begin{tabular}{|c|c|c|c|c|c|c|}
\hline & $\begin{array}{l}\text { Adequate } \\
\text { sequence } \\
\text { generation }\end{array}$ & $\begin{array}{l}\text { Allocation } \\
\text { concealment }\end{array}$ & Blinding & Outcome prespecified & $\begin{array}{l}\text { Incomplete outcome data } \\
\text { addressed }\end{array}$ & Other bias \\
\hline $\begin{array}{l}\text { Bellissimo- } \\
\text { Rodrigues }^{47}\end{array}$ & Unclear & Yes & Yes & $\begin{array}{l}\text { Mortality a defined secondary } \\
\text { endpoint. Mortality reported }\end{array}$ & $\begin{array}{l}\text { 194/200 patients analysed. Reasons } \\
\text { for exclusions discussed }\end{array}$ & - \\
\hline Berry $^{48}$ & Yes & Yes & No & Mortality not reported & $\begin{array}{l}\text { Intention to treat data obtained from } \\
\text { author }\end{array}$ & - \\
\hline Cabov $^{49}$ & Yes & Unclear & Yes & Mortality reported & Intention to treat analysis performed & - \\
\hline Fourrier $2000^{50}$ & Yes & Unclear & Partial & Mortality reported & Intention to treat analysis performed & - \\
\hline Fourrier $2005^{51}$ & Unclear & Yes & Yes & $\begin{array}{l}\text { Mortality a defined secondary } \\
\text { endpoint. Mortality reported }\end{array}$ & Intention to treat analysis performed & $\begin{array}{l}\text { Censored at } 28 \\
\text { days }\end{array}$ \\
\hline Koeman $^{52}$ & Yes & Unclear & Yes & $\begin{array}{l}\text { Mortality defined secondary } \\
\text { endpoint. Mortality reported as } \\
\text { hazard ratio only }\end{array}$ & $\begin{array}{l}\text { Intention to treat analysis possible } \\
\text { from previous communication with } \\
\text { authors }^{\star 13}\end{array}$ & - \\
\hline MacNaughton $^{53}$ & Unclear & Unclear & Yes & Mortality not reported & Unclear & $\begin{array}{l}\text { Published only in } \\
\text { abstract form }\end{array}$ \\
\hline Munro $^{54}$ & Yes & Unclear & No & $\begin{array}{l}\text { Mortality reported (subgroup of total } \\
\text { population) }\end{array}$ & $\begin{array}{l}\text { Intention to treat data obtained from } \\
\text { author }\end{array}$ & $\begin{array}{l}\text { Stopped } \\
\text { intervention at day } \\
7\end{array}$ \\
\hline Panchabhai ${ }^{55}$ & Unclear & Unclear & No & $\begin{array}{l}\text { Mortality a defined secondary } \\
\text { endpoint. Per protocol mortality } \\
\text { reported }\end{array}$ & $\begin{array}{l}471 / 512 \text { patients analysed. Reasons } \\
\text { for exclusions discussed }\end{array}$ & - \\
\hline Scannapieco ${ }^{56}$ & Yes & Yes & Yes & $\begin{array}{l}\text { Mortality a defined secondary } \\
\text { endpoint Mortality reported }\end{array}$ & $\begin{array}{l}\text { Intention to treat data obtained from } \\
\text { author }\end{array}$ & $\begin{array}{l}\text { Censored at } 21 \\
\text { days }\end{array}$ \\
\hline Tantipong ${ }^{57}$ & Unclear & Unclear & No & Mortality reported & Intention to treat analysis performed & - \\
\hline
\end{tabular}




\begin{tabular}{|c|c|c|c|c|c|c|c|c|}
\hline & Topical drugs & $\begin{array}{l}\text { Intravenous } \\
\text { drugs }\end{array}$ & Control group & Accrual period & Population & $\begin{array}{l}\text { Place study } \\
\text { undertaken }\end{array}$ & $\begin{array}{l}\text { Projected } \\
\text { ventilator or } \\
\text { ICU time }\end{array}$ & $\begin{array}{l}\text { Timing of } \\
\text { outcome }\end{array}$ \\
\hline Aerdts ${ }^{31}$ & $\begin{array}{l}\text { Polymyxin, } \\
\text { Norfloxacin, } \\
\text { Amphotericin }\end{array}$ & $\begin{array}{l}\text { Cefotaxime } 500 \\
\mathrm{mg} \text { TDS/5 days }\end{array}$ & $\begin{array}{l}\text { No antibiotic } \\
\text { prophylaxis. } 2 \\
\text { control groups: } \\
\text { either penicillin or } \\
\text { cephalosporin } \\
\text { based } \\
\text { therapeutic } \\
\text { antibiotics }\end{array}$ & $\begin{array}{l}\text { May 1986-Sep } \\
1987\end{array}$ & Mixed & $\begin{array}{l}\text { Nijmegen, } \\
\text { Netherlands }\end{array}$ & $\begin{array}{l}>5 \text { days of } \\
\text { mechanical } \\
\text { ventilation }\end{array}$ & $\begin{array}{l}\text { ICU } \\
\text { discharge }\end{array}$ \\
\hline Blair $^{32}$ & $\begin{array}{l}\text { Polymyxin, } \\
\text { Tobramycin, } \\
\text { Amphotericin }\end{array}$ & $\begin{array}{l}\text { Cefotaxime } 50 \\
\mathrm{mg} / \mathrm{kg} / \text { day } / 4 \text { days }\end{array}$ & $\begin{array}{l}\text { Standard } \\
\text { antibiotic therapy }\end{array}$ & Sep1988-Jan1990 & $\begin{array}{l}\text { Mixed, 93\% } \\
\text { ventilated }\end{array}$ & Belfast, UK & $>48 \mathrm{hr}$ in ICU & $\begin{array}{l}\text { ICU } \\
\text { discharge }\end{array}$ \\
\hline Boland $^{33}$ & $\begin{array}{l}\text { Polymyxin, } \\
\text { Tobramycin, } \\
\text { Nystatin }\end{array}$ & $\begin{array}{l}\text { Cefotaxime } / 3 \\
\text { days }\end{array}$ & Placebo & Not specified & $\begin{array}{l}\text { Multiple } \\
\text { trauma, all } \\
\text { ventilated }\end{array}$ & $\begin{array}{l}\text { Charleston, } \\
\text { WV, US }\end{array}$ & $\begin{array}{l}>5 \text { days } \\
\text { intubated }\end{array}$ & $\begin{array}{l}\text { ICU } \\
\text { discharge }\end{array}$ \\
\hline Cockerill $^{34}$ & $\begin{array}{l}\text { Polymyxin, } \\
\text { Gentamicin, } \\
\text { Nystatin }\end{array}$ & $\begin{array}{l}\text { Cefotaxime } 1 \mathrm{~g} \\
\text { TDS } / 3 \text { days }\end{array}$ & $\begin{array}{l}\text { No antibiotic } \\
\text { prophylaxis }\end{array}$ & 1986-1989 & $\begin{array}{l}\text { Mixed, } \\
\text { uninfected, } \\
85 \% \text { ventilated }\end{array}$ & $\begin{array}{l}\text { Rochester, MN, } \\
\text { US }\end{array}$ & $>3$ days in ICU & $\begin{array}{l}\text { ICU } \\
\text { discharge }\end{array}$ \\
\hline De Jonge ${ }^{18}$ & $\begin{array}{l}\text { Polymyxin, } \\
\text { Tobramycin, } \\
\text { Amphotericin }\end{array}$ & $\begin{array}{l}\text { Cefotaxime } 1 \mathrm{~g} \\
\text { QDS/4 days }\end{array}$ & $\begin{array}{l}\text { No antibiotic } \\
\text { prophylaxis }\end{array}$ & $\begin{array}{l}\text { Sep 1999- Dec } \\
2001\end{array}$ & $\begin{array}{l}\text { Mixed, } 85 \% \\
\text { ventilated }\end{array}$ & $\begin{array}{l}\text { Amsterdam, } \\
\text { Netherlands }\end{array}$ & $\begin{array}{l}>48 \mathrm{hr} \text { of } \\
\text { mechanical } \\
\text { ventilation or } 3 \\
\text { days in ICU }\end{array}$ & $\begin{array}{l}\text { ICU } \\
\text { discharge }\end{array}$ \\
\hline De Smet ${ }^{19}$ & $\begin{array}{l}\text { Polymyxin, } \\
\text { Tobramycin, } \\
\text { Amphotericin }\end{array}$ & $\begin{array}{l}\text { Cefotaxime } 1 \mathrm{~g} \\
\text { QDS } / 4 \text { days, or } \\
\text { none. }\end{array}$ & $\begin{array}{l}\text { No antibiotic } \\
\text { prophylaxis }\end{array}$ & $\begin{array}{l}\text { May 2004-July } \\
2006\end{array}$ & $\begin{array}{l}\text { Mixed, } 90 \% \\
\text { ventilated }\end{array}$ & $\begin{array}{l}\text { Multiple sites } \\
(13), \\
\text { Netherlands }\end{array}$ & $\begin{array}{l}>48 \mathrm{hr} \text { of } \\
\text { mechanical } \\
\text { ventilation or } 3 \\
\text { days in ICU }\end{array}$ & 28 days \\
\hline Jacobs $^{35}$ & $\begin{array}{l}\text { Polymyxin, } \\
\text { Tobramycin, } \\
\text { Amphotericin }\end{array}$ & $\begin{array}{l}\text { Cefotaxime } 50 \\
\mathrm{mg} / \mathrm{kg} / \text { day/4 days }\end{array}$ & $\begin{array}{l}\text { Normal } \\
\text { management. } \\
\text { Low gastric pH } \\
\text { encouraged. }\end{array}$ & $\begin{array}{l}\text { July 1989-Aug } \\
1990\end{array}$ & $\begin{array}{l}\text { Mixed, } 50 \% \\
\text { neurological, } \\
\text { all ventilated }\end{array}$ & Cardiff, UK & $>3$ days in ICU & Unclear \\
\hline Kreuger $^{36}$ & $\begin{array}{l}\text { Polymyxin, } \\
\text { Gentamicin } \\
\text { (Vancomycin \& } \\
\text { Amphotericin) }\end{array}$ & $\begin{array}{l}\text { Ciprofloxacin } 400 \\
\text { mg BD/4 days }\end{array}$ & Placebo & $\begin{array}{l}2.5 \mathrm{yr} \text {, dates not } \\
\text { given (published } \\
2002 \text { ) }\end{array}$ & $\begin{array}{l}90 \% \text { surgical } \\
\text { and trauma }\end{array}$ & $\begin{array}{l}2 \text { sites, } \\
\text { Tübingen, } \\
\text { Germany }\end{array}$ & $>48 \mathrm{hr}$ in ICU & $\begin{array}{l}\text { ICU } \\
\text { discharge }\end{array}$ \\
\hline Palomar $^{37}$ & $\begin{array}{l}\text { Polymyxin, } \\
\text { Tobramycin, } \\
\text { Amphotericin }\end{array}$ & $\begin{array}{l}\text { Cefotaxime } 1 \mathrm{~g} \\
\text { TDS } / 4 \text { days }\end{array}$ & $\begin{array}{l}\text { No antibiotic } \\
\text { prophylaxis }\end{array}$ & $\begin{array}{l}\text { July 1989- July } \\
1991\end{array}$ & $\begin{array}{l}\text { Mixed, } \\
\text { uninfected }\end{array}$ & $\begin{array}{l}\text { Multiple sites } \\
(10), \text { Catalonia, } \\
\text { Spain }\end{array}$ & $\begin{array}{l}>4 \text { days of } \\
\text { mechanical } \\
\text { ventilation }\end{array}$ & $\begin{array}{l}\text { ICU } \\
\text { discharge }\end{array}$ \\
\hline Rocha $^{38}$ & $\begin{array}{l}\text { Polymyxin, } \\
\text { Tobramycin, } \\
\text { Amphotericin }\end{array}$ & $\begin{array}{l}\text { Cefotaxime } 2 \mathrm{~g} \\
\text { TDS } / 4 \text { days }\end{array}$ & Placebo & $\begin{array}{l}14 \text { months, dates } \\
\text { not given } \\
\text { (published 1992) }\end{array}$ & $\begin{array}{l}80 \% \text { trauma, } \\
\text { uninfected }\end{array}$ & $\begin{array}{l}\text { La Coruna, } \\
\text { Spain }\end{array}$ & $\begin{array}{l}>3 \text { days of } \\
\text { mechanical } \\
\text { ventilation and > } \\
5 \text { days ICU stay }\end{array}$ & $\begin{array}{l}\text { ICU } \\
\text { discharge }\end{array}$ \\
\hline Sanchez-Garcia ${ }^{39}$ & $\begin{array}{l}\text { Polymyxin, } \\
\text { Gentamicin, } \\
\text { Amphotericin }\end{array}$ & $\begin{array}{l}\text { Ceftriaxone } 2 \mathrm{~g} \\
\text { OD/3 days }\end{array}$ & Placebo & $\begin{array}{l}\text { Not stated } \\
\text { (published 1998) }\end{array}$ & $\begin{array}{l}\text { Mixed, } 70 \% \\
\text { medical }\end{array}$ & $\begin{array}{l}\text { Multiple sites } \\
\text { (5), Madrid, } \\
\text { Spain }\end{array}$ & $\begin{array}{l}>48 \mathrm{hr} \text { of } \\
\text { intubation }\end{array}$ & $\begin{array}{l}\text { ICU } \\
\text { discharge }\end{array}$ \\
\hline Stoutenbeek ${ }^{40}$ & $\begin{array}{l}\text { Polymyxin, } \\
\text { Tobramycin, } \\
\text { Amphotericin }\end{array}$ & $\begin{array}{l}\text { Cefotaxime } 1 \mathrm{~g} \\
\text { QDS/4 days }\end{array}$ & $\begin{array}{l}\text { Standard } \\
\text { antibiotic therapy } \\
\text { for each centre }\end{array}$ & $\begin{array}{l}\text { Oct 1991-June } \\
1994\end{array}$ & $\begin{array}{l}\text { Blunt multi } \\
\text { trauma, all } \\
\text { ventilated }\end{array}$ & $\begin{array}{l}\text { Multiple sites } \\
\text { (17): Europe, } \\
\text { Australia, New } \\
\text { Zealand }\end{array}$ & Not a criterion & $\begin{array}{l}\text { ICU } \\
\text { discharge or } \\
\text { up to } 2 \\
\text { weeks } \\
\text { following ICU } \\
\text { discharge }\end{array}$ \\
\hline Ulrich $^{41}$ & $\begin{array}{l}\text { Polymyxin, } \\
\text { Norfloxacin, } \\
\text { Amphotericin }\end{array}$ & $\begin{array}{l}\text { Trimethoprim } 500 \\
\text { mg OD/3 days }\end{array}$ & $\begin{array}{l}\text { Appropriate } \\
\text { perioperative } \\
\text { prophylaxis }\end{array}$ & $\begin{array}{l}\text { Oct 1986-Sep } \\
1987\end{array}$ & Mixed & $\begin{array}{l}\text { Hague, } \\
\text { Netherlands }\end{array}$ & $>5$ days in ICU & $\begin{array}{l}\text { ICU } \\
\text { discharge }\end{array}$ \\
\hline Verwaest $^{42}$ & $\begin{array}{l}\text { Ofloxacin, } \\
\text { Amphotericin }\end{array}$ & $\begin{array}{l}\text { Ofloxacin } 200 \mathrm{mg} \\
\text { OD/4 days }\end{array}$ & $\begin{array}{l}\text { Conventional } \\
\text { antibiotic policy }\end{array}$ & $\begin{array}{l}19 \text { months, dates } \\
\text { not given } \\
\text { (published 1997) }\end{array}$ & $\begin{array}{l}75 \% \text { surgical, } \\
\text { third cardiac }\end{array}$ & $\begin{array}{l}\text { Leuven, } \\
\text { Belgium }\end{array}$ & $\begin{array}{l}>48 \mathrm{hr} \text { of } \\
\text { mechanical } \\
\text { ventilation }\end{array}$ & $\begin{array}{l}\text { ICU } \\
\text { discharge }\end{array}$ \\
\hline Winter $^{43}$ & $\begin{array}{l}\text { Polymyxin, } \\
\text { Tobramycin, } \\
\text { Amphotericin }\end{array}$ & $\begin{array}{l}\text { Ceftazidime } 50 \\
\mathrm{mg} / \mathrm{kg} / \text { day } / 3 \text { days }\end{array}$ & Nothing specified & $\begin{array}{l}22 \text { months, dates } \\
\text { not given } \\
\text { (published 1992) }\end{array}$ & Mixed & Bristol, UK & $>48 \mathrm{hr}$ in ICU & $\begin{array}{l}\text { Hospital } \\
\text { discharge }\end{array}$ \\
\hline
\end{tabular}


Table 5| Other aspects of included trials on effect of selective oropharyngeal decontamination (SOD) for prevention of death in adults in intensive care

\begin{tabular}{|c|c|c|c|c|c|c|c|}
\hline & Topical drugs & Control group & Accrual period & Population & $\begin{array}{l}\text { Place study } \\
\text { undertaken }\end{array}$ & $\begin{array}{l}\text { Projected ventilator or } \\
\text { ICU time }\end{array}$ & $\begin{array}{l}\text { Timing of } \\
\text { outcome }\end{array}$ \\
\hline Bergmans $^{44}$ & $\begin{array}{l}\text { Gentamicin, Polymyxin, } \\
\text { Vancomycin / QDS }\end{array}$ & Placebo & $\begin{array}{l}\text { Sep 1994-Dec } \\
1996\end{array}$ & $\begin{array}{l}\text { Mixed ICU, all } \\
\text { ventilated }\end{array}$ & $\begin{array}{l}\text { Multiple sites (3), } \\
\text { Netherlands }\end{array}$ & $\begin{array}{l}>48 \mathrm{hr} \text { of mechanical } \\
\text { ventilation }\end{array}$ & ICU discharge \\
\hline Pugin ${ }^{45}$ & $\begin{array}{l}\text { Polymyxin, Neomycin, } \\
\text { Vancomycin / } 4 \text { hourly }\end{array}$ & Placebo & Apr-Nov 1989 & $\begin{array}{l}\text { Surgical ICU, all } \\
\text { ventilated }\end{array}$ & Geneva, Switzerland & $>48 \mathrm{hr}$ of intubation & Hospital discharge \\
\hline $\operatorname{Rios}^{46}$ & $\begin{array}{l}\text { Polymyxin, Gentamicin / } \\
\text { TDS }\end{array}$ & Placebo & Uncertain & Uncertain & $\begin{array}{l}\text { Buenos Aires, } \\
\text { Argentina }\end{array}$ & $\begin{array}{l}>4 \text { days of mechanical } \\
\text { ventilation }\end{array}$ & Unclear \\
\hline
\end{tabular}




\begin{tabular}{|c|c|c|c|c|c|c|c|}
\hline & Chlorhexidine & Control group & Accrual period & Population & $\begin{array}{l}\text { Place study } \\
\text { undertaken }\end{array}$ & $\begin{array}{l}\text { Projected ventilator } \\
\text { or ICU time }\end{array}$ & $\begin{array}{l}\text { Timing of } \\
\text { outcome }\end{array}$ \\
\hline $\begin{array}{l}\text { Bellissimo- } \\
\text { Rodrigues }^{47}\end{array}$ & $\begin{array}{l}0.12 \% \text { solution } \\
\text { TDS }\end{array}$ & Placebo & Mar 2006-Feb 2008 & $\begin{array}{l}\text { Mixed ICU, } 69 \% \\
\text { ventilated }\end{array}$ & Sao Paulo, Brazil & $>48 \mathrm{hr}$ in ICU & ICU discharge \\
\hline Berry ${ }^{48}$ & $0.2 \%$ solution $\mathrm{BD}$ & $\begin{array}{l}\text { Either water or } \\
\text { bicarbonate mouth } \\
\text { rinses }\end{array}$ & $\begin{array}{l}\text { Uncertain, } 15 \text { month } \\
\text { recruitment period }\end{array}$ & $\begin{array}{l}\text { Mixed ICU, } 100 \% \\
\text { ventilated }\end{array}$ & Sydney, Australia & Not specified & ICU discharge \\
\hline Cabov $^{49}$ & $0.2 \%$ gel TDS & Placebo & $\begin{array}{l}\text { Mar 2008- Dec } \\
2008\end{array}$ & $\begin{array}{l}\text { Surgical ICU, 100\% } \\
\text { ventilated }\end{array}$ & Zagreb, Croatia & $\begin{array}{l}>3 \text { days in ICU and } \\
\text { requiring mechanical } \\
\text { ventilation }\end{array}$ & ICU discharge \\
\hline Fourrier $2000^{50}$ & $0.2 \%$ gel TDS & $\begin{array}{l}\text { Bicarbonate } \\
\text { mouth rinses }\end{array}$ & $\begin{array}{l}\text { June 1997- July } \\
1998\end{array}$ & $\begin{array}{l}\text { Mixed ICU, } 100 \% \\
\text { ventilated }\end{array}$ & Lille, France & $\begin{array}{l}>5 \text { days in ICU and } \\
\text { requiring mechanical } \\
\text { ventilation }\end{array}$ & Unclear \\
\hline Fourrier $2005^{51}$ & $0.2 \% \mathrm{gel}$ TDS & Placebo & Jan 2001-Sep 2002 & $\begin{array}{l}\text { Mixed ICU, 100\% } \\
\text { ventilated }\end{array}$ & $\begin{array}{l}\text { Multiple sites (6), } \\
\text { Lille, France }\end{array}$ & $\begin{array}{l}>5 \text { days in ICU and } \\
\text { requiring mechanical } \\
\text { ventilation }\end{array}$ & 28 days \\
\hline Koeman $^{52}$ & $2 \%$ gel QDS & Placebo & $\begin{array}{l}\text { Feb } 2001-\text { Mar } \\
2003\end{array}$ & $\begin{array}{l}\text { Mixed ICU, 100\% } \\
\text { ventilated }\end{array}$ & $\begin{array}{l}\text { Multiple sites (7), } \\
\text { Netherlands }\end{array}$ & $\begin{array}{l}>48 \mathrm{hr} \text { of mechanical } \\
\text { ventilation }\end{array}$ & ICU discharge \\
\hline MacNaughton $^{53}$ & $0.2 \% \mathrm{BD}$ & Placebo & Uncertain & $\begin{array}{l}\text { Mixed ICU, 100\% } \\
\text { ventilated }\end{array}$ & Plymouth, UK & $\begin{array}{l}>48 \mathrm{hr} \text { of mechanical } \\
\text { ventilation }\end{array}$ & ICU discharge \\
\hline Munro $^{54}$ & $\begin{array}{l}0.12 \% \text { solution } \\
\mathrm{BD}\end{array}$ & $\begin{array}{l}\text { Either usual care } \\
\text { or toothbrushing } \\
\text { groups }\end{array}$ & Uncertain & $\begin{array}{l}\text { Mixed ICU, 100\% } \\
\text { ventilated }\end{array}$ & Richmond, VA, US & Not specified. & $\begin{array}{l}\text { Hospital } \\
\text { discharge }\end{array}$ \\
\hline Panchabhai ${ }^{55}$ & $\begin{array}{l}0.12 \% \text { solution } \\
\mathrm{BD}\end{array}$ & $\begin{array}{l}0.01 \% \text { potassium } \\
\text { permanganate }\end{array}$ & $\begin{array}{l}\text { Uncertain, } 8 \text { month } \\
\text { recruitment period }\end{array}$ & $\begin{array}{l}\text { Mediconeuro ICU, } \\
\text { 171/471 ventilated }\end{array}$ & Mumbai, India & $>48 \mathrm{hr}$ in ICU & ICU discharge \\
\hline Scannapieco ${ }^{56}$ & $\begin{array}{l}0.12 \% \text { solution } \\
\text { OD or BD }\end{array}$ & Placebo & Mar 2004-Nov 2007 & $\begin{array}{l}\text { Trauma ICU, 100\% } \\
\text { ventilated }\end{array}$ & Buffalo, NY, US & Not specified & 21 days \\
\hline Tantipong $^{57}$ & $2 \%$ solution QDS & Normal saline & Jan 2006-Mar 2007 & $\begin{array}{l}\text { Surgical or medical ICU } \\
\text { or general medical } \\
\text { ward, } 100 \% \text { ventilated }\end{array}$ & Bangkok, Thailand & Not specified & Unclear \\
\hline
\end{tabular}


Table 7| Results of meta-analyses of effect of selective digestive decontamination (SDD), selective oropharyngeal decontamination (SOD), and topical oropharyngeal chlorhexidine for prevention of death in adults in intensive care

OR (95\% Cl/Crl)

Comparison Direct evidence Mixed (direct and indirect) evidence

Chlorhexidine $v$ control 1.25 (1.05 to 1.50$) \quad 1.23$ (0.99 to 1.49$)$

SDD $v$ control $\quad 0.73(0.64$ to 0.84$) \quad 0.74(0.63$ to 0.86$)$

SOD $v$ control $\quad 0.85(0.74$ to 0.97$) \quad 0.82(0.62$ to 1.02$)$

SDD $v$ chlorhexidine $\quad-\quad 0.61(0.47$ to 0.78$)$

SOD $v$ chlorhexidine $\quad-\quad 0.67$ ( 0.48 to 0.91$)$

SDD $v$ SOD $\quad 0.97(0.79$ to 1.18$) \quad 0.91(0.70$ to 1.19$)$ 
Table 8| Probabilistic ranking of interventions and estimated probability of death in adults in intensive care treated with selective digestive decontamination (SDD), selective oropharyngeal decontamination (SOD), or topical oropharyngeal chlorhexidine

Intervention Rank Estimated probability of death Probability of intervention being best

\begin{tabular}{llll} 
SDD & 1 & 0.213 & 0.740 \\
\hline SOD & 2 & 0.228 & 0.260 \\
\hline Control & 3 & 0.266 & $<0.001$ \\
\hline Chlorhexidine & 4 & 0.305 & $<0.001$ \\
\hline
\end{tabular}




\section{Figures}

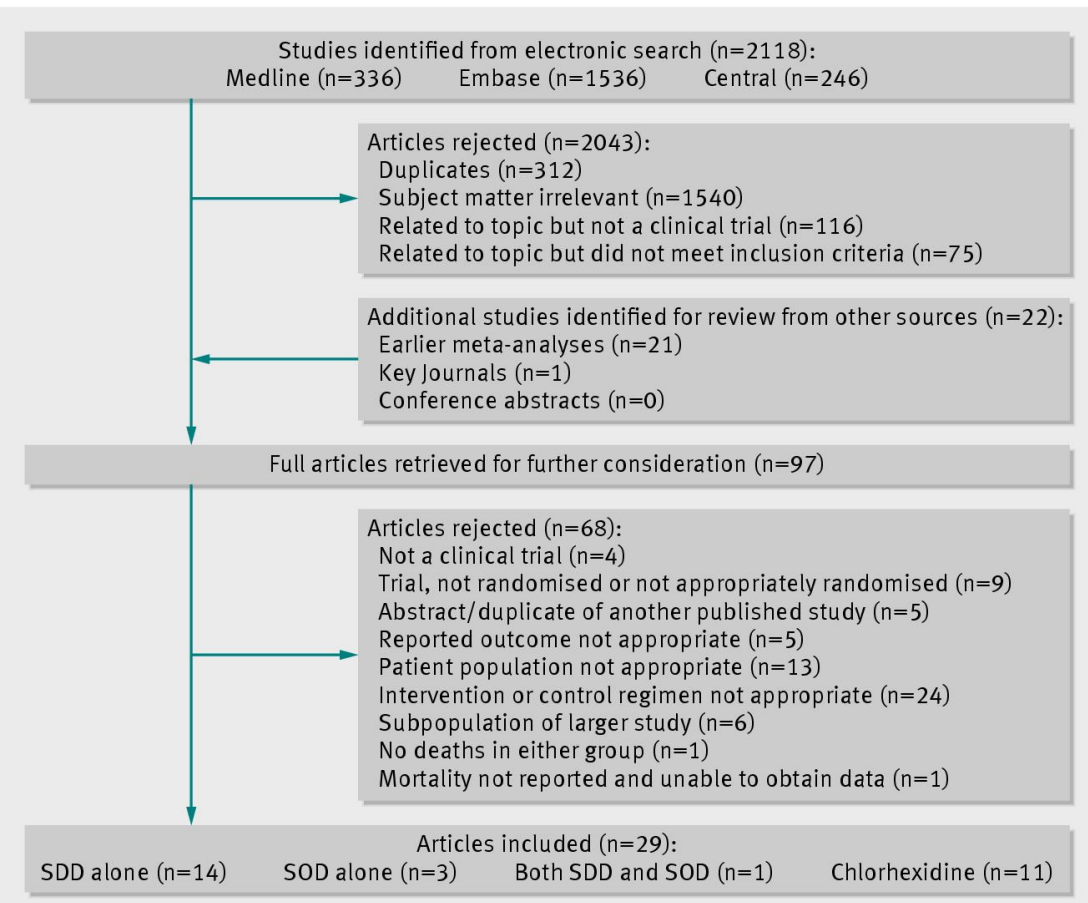

Fig 1 Inclusion of studies in analysis of effect of selective digestive decontamination (SDD), selective oropharyngeal decontamination (SOD), and topical oropharyngeal chlorhexidine for prevention of death in adults in intensive care

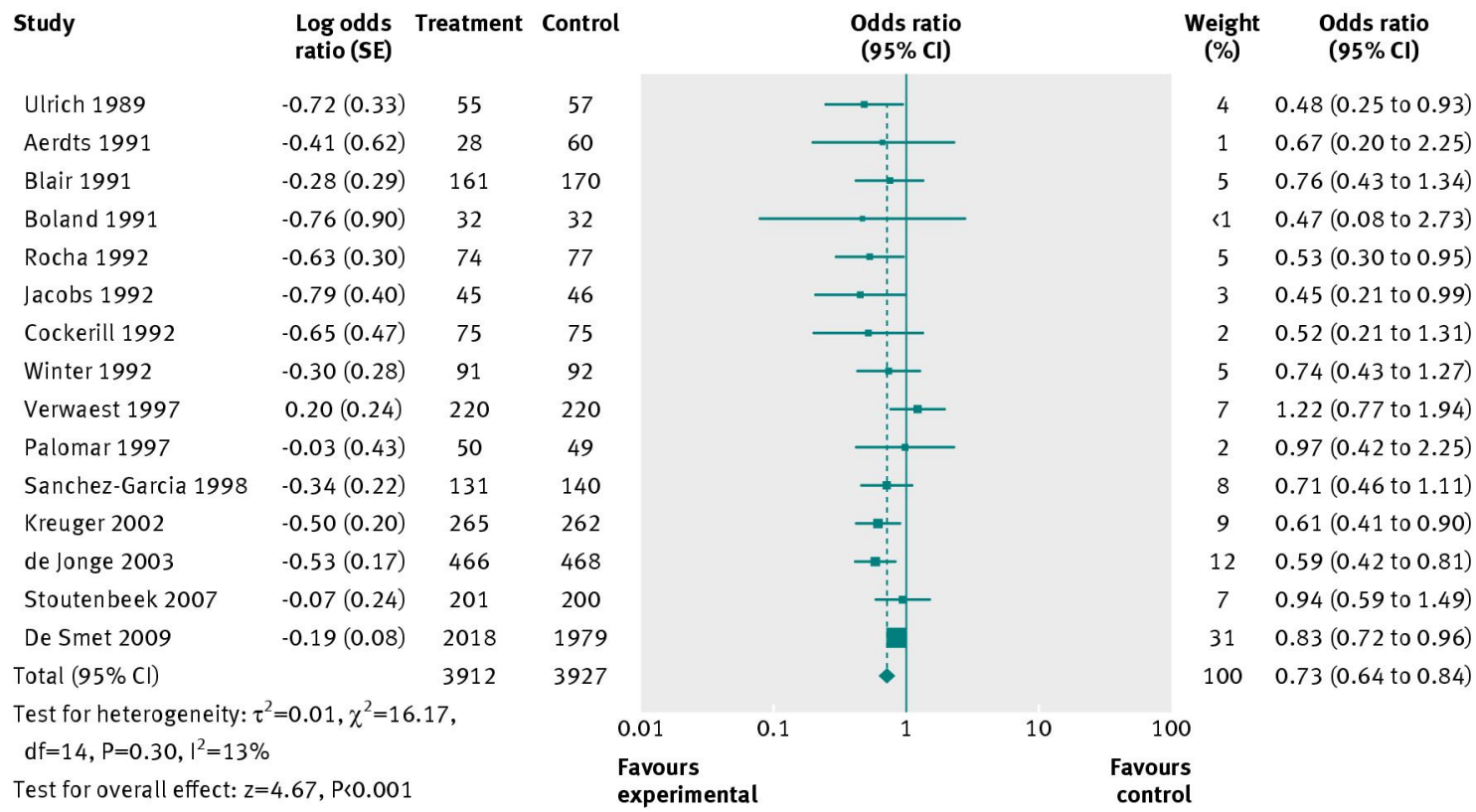

Fig 2 Forest plot of intervention-control pairwise meta-analysis of selective digestive decontamination $v$ control in adult patients in intensive care 


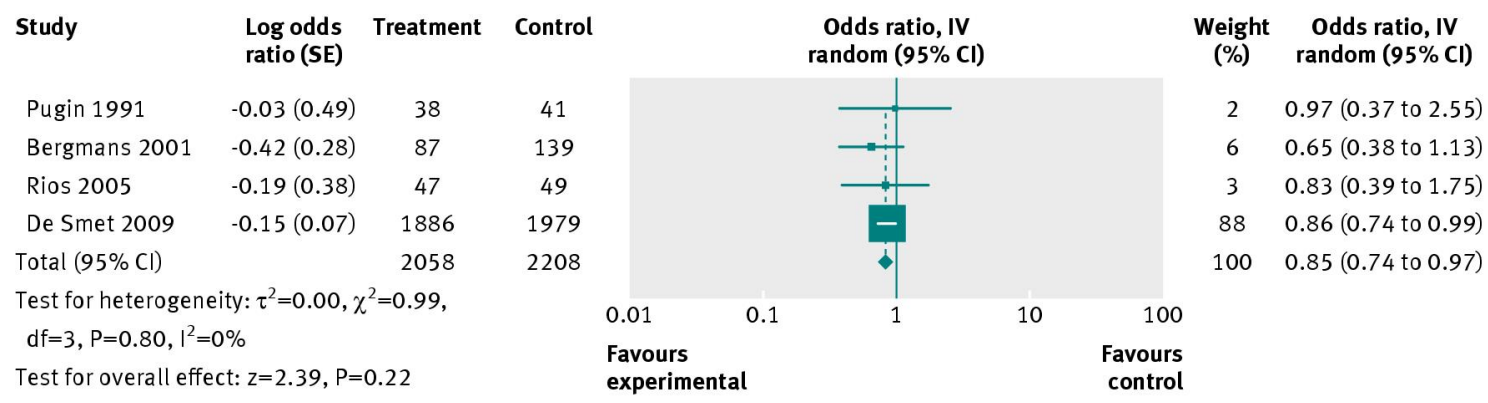

Fig 3 Forest plot of intervention-control pairwise meta-analysis of selective oropharyngeal decontamination $v$ control in adult patients in intensive care

\begin{tabular}{|c|c|c|c|c|c|c|c|}
\hline \multirow{3}{*}{$\begin{array}{l}\text { Study } \\
\text { Fourier } 2000\end{array}$} & \multicolumn{2}{|c|}{ No of events/total } & \multirow{2}{*}{\multicolumn{3}{|c|}{$\begin{array}{l}\text { Odds ratio, } \mathrm{M}-\mathrm{H} \\
\text { random }(95 \% \mathrm{Cl})\end{array}$}} & \multirow[b]{2}{*}{$\begin{array}{c}\text { Weight } \\
\text { (\%) }\end{array}$} & \multirow[b]{2}{*}{$\begin{array}{l}\text { Odds ratio, } \mathrm{M}-\mathrm{H} \\
\text { random }(95 \% \mathrm{Cl})\end{array}$} \\
\hline & Treatment & Control & & & & & \\
\hline & $3 / 30$ & $7 / 30$ & & $T$ & & 2 & 0.37 (0.08 to 1.58$)$ \\
\hline MacNaughton 2004 & $29 / 101$ & $29 / 93$ & & & & 8 & 0.89 (0.48 to 1.64$)$ \\
\hline Fourrier 2005 & $31 / 114$ & $24 / 114$ & & & & 9 & $1.40(0.76$ to 2.58$)$ \\
\hline Koeman 2006 & $49 / 127$ & $39 / 130$ & & & & 12 & $1.47(0.87$ to 2.46$)$ \\
\hline Tantipong 2008 & $36 / 102$ & $37 / 105$ & & & & 10 & $1.00(0.57$ to 1.77$)$ \\
\hline Scannapieco 2009 & $19 / 116$ & $9 / 59$ & & & & 4 & 1.09 (0.46 to 2.58$)$ \\
\hline Bellissimo-Rodrigues 2009 & $935 / 98$ & $33 / 96$ & & : & & 9 & $1.06(0.59$ to 1.91$)$ \\
\hline Munro 2009 & $69 / 275$ & $47 / 272$ & & - & & 18 & 1.60 (1.06 to 2.43$)$ \\
\hline Panchabhai 2009 & $78 / 224$ & $70 / 247$ & & 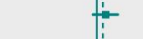 & & 21 & $1.35(0.91$ to 2.00$)$ \\
\hline Cabov 2010 & $1 / 30$ & $3 / 30$ & & T & & $\ll 1$ & 0.31 (0.03 to 3.17$)$ \\
\hline Berry 2011 & $17 / 71$ & $28 / 154$ & & is & & 7 & $1.42(0.72$ to 2.80$)$ \\
\hline Total $(95 \% \mathrm{Cl})$ & $367 / 1288$ & $326 / 1330$ & & $b$ & & 100 & $1.25(1.05$ to 1.50$)$ \\
\hline $\begin{array}{l}\text { Test for heterogeneity: } \tau^{2}=0 \text {. } \\
d f=10, P=0.59,\left.\right|^{2}=0 \% \\
\text { Test for overall effect: } z=2.4\end{array}$ & $\begin{array}{l}.00, \chi^{2}=8.41 \\
47, P=0.01\end{array}$ & & $\begin{array}{l}0.01 \\
\text { Favou } \\
\text { exper }\end{array}$ & $\begin{array}{l}\text { irs } \\
\text { imental }\end{array}$ & & $\begin{array}{l}100 \\
\text { ours } \\
\text { ntrol }\end{array}$ & \\
\hline
\end{tabular}

Fig 4 Forest plot of intervention-control pairwise meta-analysis of chlorhexidine $v$ control in adult patients in intensive care 